\title{
Almanya, Amerika Birleşik Devletleri, Fransa, İngiltere ve Türkiye'de Genel Lise Sosyal Bilimler Programlarının Karşılaştırılması
}

\author{
Metin AŞCIab, Mehmet A. KISAKÜREK
}

Özet

Anahtar Kelimeler

Almanya, Amerika Birleşik Devletleri, Fransa, İngiltere ve Türkiye'deki genel liselerde okutulan Sosyal Bilimler programları ile sınırlandırılan bu çalışma konusu gereği uluslararası karşılaştırmalı bir çalışmadır. Nitel araştırma yönteminin kullanıldığı bu çalışmada İnternet üzerinden ulaşılan ilgili ülkelerin lise Sosyal Bilimler programlarından ve bu programlar hakkında yayımlanan makalelerden elde edilen veriler karşılaştırmalı eğitimin kendine özgü analiz yöntemlerine uygun olarak benzerlik ve farklılıklar açısından analiz edilmiştir. Araştırma sorularından yola çıkılarak veri analizi için bir çerçeve oluşturulmuştur. Bu çerçeveye göre veriler seçilmiş, düzenlenmiş, benzerlik ve farklılıklar bir araya getirilmiş, karşılaştırılmış ve yorumlanmıştır. Çalışma bulguları açısından ele alındığında görülmektedir ki genel lise programlarında sosyal bilimler derslerine niceliksel olarak ağırlık veren ülke Türkiye'dir. Türkiye'deki genel lise programlarında 13 Sosyal Bilim dersi bulunmaktadır. Genel lise programları Sosyal Bilimler öğretimi açısından incelenen ülkelerden A.B.D. Almanya ve Fransa'da lise Sosyal Bilim derslerinin bütünleştirilmesine yönelik eğilimler tespit edilmiştir.

Çalışma sonuçları, Türkiye'de genel liselerde okutulan Sosyal Bilimler derslerinin tek disiplin içinde yaklaşımının parçalı modeline göre disipliner bir anlayışla lise programlarına eklendiğini ortaya koymuştur.

\section{A Comparison of the Curricula of Social Sciences Courses at Upper Secondary Level in Germany, U.S.A., France, England, and Turkey}

\section{Abstract}

In this study, the curricula of Social Sciences courses (history, geography, citizenship, economics ) at the upper secondary level, the objectives, contents, instruction and assessment methods and techniques of the courses in Turkey, Germany, France, England and the USA are compared. Based on the data and using mainly the horizontal approach, a curriculum model is suggested for the social science education at the upper secondary level in Turkey.

The websites of the ministries of education and related networks were investigated and curricula of social sciences courses, related laws as well as articles accessed were made use of through documentary and literary survey method in completing the study. The findings of the study show that social science teaching at the upper secondary level in Turkey is based on a disciplinary approach and puts emphasis on national elements. It is essential to implement an inter-discipliner approach in social science teaching at the upper secondary level in Turkey or employ some thematic strands which consist of both national and universal themes and values to construct new curricula of social sciences courses.
Eğitim Programları

Sosyal Bilimler

Karşılaştırmalı Eğitim

Makale Hakkında

Geliş Tarihi: 29.11.2018

Kabul Tarihi: 26.03.2021

Doi: 10.18026/cbayarsos.489597
Keywords

Curricula

Social Sciences

Comparative Education

About Article

Received: $29 . .2018$

Accepted: 26.03.2021

Doi: 10.18026/cbayarsos.489597

a İletişim yazarı: okan_metin@hotmail.com

b Manisa Celal Bayar Üniversitesi Eğitim Fakültesi Eğitim Bilimleri Bölümü. 


\section{Giriş}

Hızla değişen ve küreselleşen bir dünyada artık ulusal değerlerin yanında küresel değerler de Sosyal Bilimler öğretiminde programlara dahil edilmektedir. Sosyal Bilimlerin insan ve toplum yaşamını doğrudan ilgilendiren aktüel konuları ele alması bu alanın çağı yakalamadaki önemini ortaya koymaktadır. Sosyal Bilimlerin ne olduğu ve kapsadığı alanlar açısından literatür incelendiğinde farklı tanımlar ve alan sınıflamaları ile karşılaşılmaktadır. Sözü edilen bu farklılı̆̆ın nedeni; Sosyal Bilimler alanlarının sınıflandırılmasının, sınıflamayı yapanın amacına göre değişmesidir (Kısakürek 1981)

Aynı şekilde (Sözer, 1998) çeşitli kaynaklarda, Sosyal Bilimlerin değişik tanımlamaları yapılıp, değişik bölümlemeleri olduğuna dikkati çekmektedir. Bu bakımdan, Sosyal Bilimler kapsamına giren alanları kesin çizgilerle birbirinden ayırmanın güç olduğunu belirtmektedir. Seligman (1968) sosyal bilimler ansiklopedisinde, sosyal bilimleri; bireylerin, toplumun üyeleri olarak davranış ve ilişkililerini inceleyen kültürel ve zihinsel bilimler olarak tanımlamaktadır (Akt,Özoğlu 1974). Varış, Sosyal Bilimlerin bilgi yapısı açısından bir tasnif olduğunu belirtirken, Sosyal Bilimlerin insanoğlunun sosyal ilişkilerini konu edinen bir bilgi kategorisi olduğuna değinmektedir. Sosyal bilimlerin kendi içindeki ilişkilerini; disiplinler arası görüş, çeşitli disiplinlerden yaklaşım ve indirgeyici görüş olarak üçe ayırmaktadır (Varış, 1988). Gardner ve diğerleri ise Sosyal Bilimleri; bilimsel bir tutumla toplumların incelendiği disiplinler olarak ele almaktadırlar (Gardner ve Diğerleri, 1998).

Farklı tanımların ortak noktaları ele alındığında Sosyal Bilimlerin, insanoğlu ile ilgili olan bilim dallarından Tarih, Coğrafya, Yurttaşlık Bilgisi, Felsefe, Antropoloji, Sosyoloji, Psikoloji ve Ekonomi alanlarında sistemli ve bilimsel çalışmaların tümüne verilen ad olduğu görülmektedir. Genel anlamda belirtilen disiplinleri kapsayan Sosyal Bilimlerin oldukça uzun bir geçmişe sahip olduğu ve bugün kabul gören şeklinin oluşmasında bazı evrelerden geçtiği bilinmektedir.

Günümüzde ise Sosyal Bilimler, özellikle bölge araştırmaları sırasında ortaya çıkan sonuçlar 1şığında disiplinler arası çalışmalara yoğunlaşmıştır. Son yıllarda bilginin önlenemez çoğalışı Sosyal Bilimler alanındaki disiplinlerin kendi içinde bölünmelerine ve hatta farklı disiplinler arasında ara disiplinlerin oluşmasına sebep olmuştur. Sosyal bilimlerin gelişmesi ve sosyal bilimler alanında yeni çalışmaların ortaya çıkmasının sonucu olarak sosyal bilimler ile uğraşan sosyal bilimcilerin nasıl yetiştirilmesi gerektiği ve nitelikleri kendi de bir sosyal bilim olan eğitim bilimlerinin konusunu oluşturmuştur.

Sosyal Bilimlerin köklerine inildiğinde ; Felsefe ile karşılaşılmaktadır. Felsefe alanı başlangıçta bilimlerin tümünü içinde barındıran bir alan olarak karşımıza çıkmaktadır. Yurtal, bilginin gelişimi, özerk dallara ayrılması ve her bölümün kendi içinde çok daha fazla uzmanlık gerektirmesiyle zaman içinde bilimlerin felsefeden ayrışmaya başladığını belirterek, önce doğa bilimlerinin sonra giderek sosyal bilimlerin ayrışmaya başladığını vurgulamaktadır

\section{Sosyal Bilimlerin Tarihsel Gelişimi}

Sözer (1998) 19. Yüzyıla girmeden önce, bugünkü bilinen anlamda Sosyal Bilimlerden söz etmenin pek olanaklı olmadığını belirtip, bu alanların ayrı birer disiplin olarak kabul edilişlerinin, politika ve sanayi alanındaki büyük devrimlerin sonrasına rastladığını ortaya koymuştur. Sözer, Sosyal Bilimlerin 19.Yüzyıldaki gelişiminde rolü olan düşüncelerin, aslında 17. ve 18. Yüzyıllarda ortaya çıktığını, Sosyal Bilimlerin temel konularının, Fransız ve 
sanayi devriminin eski toplumsal düzeni sarsması ile ortaya çıkan sorunlara çözüm arayışlarından doğduğunu açıklamaktadır.

Daha sonra 19.yüzyıl boyunca farklı disiplinler, değişik epistemolojik tavırlardan oluşan bir yelpaze gibi açılmıştır. Yelpazenin bir ucunda Matematik, diğer ucunda deneysel Doğa Bilimleri bulunmaktaydı. Diğer tarafta ise belli başlı sanatsal faaliyetleri inceleyen edebiyat, resim, heykel alanları, çoğu zaman da uygulamada bu sanatların tarihini ele aldığı için tarihe yaklaşan İnsan Bilimleri durmaktaydı. İnsan bilimlerinin tam yanında da "Sosyal Bilim" bulunmaktaydı (Gulbenkian Komisyonu, 1995)

19. yüzyıla damgasını vuran Fransız Devrimi ve Sanayi Devrimi sosyal bilimdeki disiplinleşmenin kilometre taşları sayılmaktaydı. Güven, bu süreci şöyle belirtmektedir; "Fransız Devrimi ile meydana gelen sosyal değişimin sebeplerinin araştırılması, bu değişime yön verme ve toplumun sorunlarını formüle etme ihtiyacı Sosyal Bilimlere bakışın değişmesine yol açmıştır. 1850 ile 1945 yılları arasında, ayrı bir bilgi alanı oluşturdukları kabul edilen bir dizi disiplin ortaya çıtı ve bu yeni alana "Sosyal Bilim" adı verildi. Bu gelişme belli başlı üniversitelerde önce kürsüler, daha sonra her disiplinde diplomaya yönelik ders programları öneren bölümler kurularak sağlanmıştır". (Güven,2005)

Bu dönemde Sosyal Bilimlerin yapılanmasında önemli rol oynayan disiplinleşme sistemi üç değişik ayrım çizgisini de beraberinde getirmiştir. Bunlar;

1- Modern/uygar dünyayı inceleyen dallar (tarih ve üç nomotetik bilim) ile modern olmayan dünyayı inceleyen dallar (antropoloji ve doğu araştırmaları)arasındaki ayrım. 2- Modern dünyayı inceleyen bilim dalları arasında, geçmişi inceleyenlerle (tarih) bugünü inceleyenler (nomotetik sosyal bilimler) arasındaki ayrım.3-Nomotetik ve Sosyal Bilimler arasında piyasayı (iktisat), devleti (siyasal bilim) ve sivil toplumu (sosyoloji) inceleyenler arasındaki keskin ayrım olmuştur.

1945 sonrası dünyada bu ayırım çizgilerinin her biri tartışma konusu olmuştur. Bu komisyonun raporu doğrultusunda belirtilen süreçte ise Sosyal Bilimler alanında yapılan araştırmalar, daha çok bölge araştırmaları şeklindedir. O dönemde Amerika Birleşik Devletleri'nin durdurulamaz yükselişi sözü edilen bölge araştırmalarının bu ülkede şekillenip dünyaya yayılmasına sebep olmuştur. Bölge araştırmalarının altında aslında oldukça basit ve anlaşılır bir mantık yatmaktadır. Bir bölge, tarihi, coğrafyası, ekonomisi ve kültürüyle bir bütündür. Böylesine bir bütünlük bölge araştırmalarında çok disiplinli bir yaklaşımı da zorunlu hale getirmektedir. Tarihçi belirlenen bir bölgenin tarihini incelerken, coğrafyacı o bölgenin coğrafyasını, ekonomist o bölgenin ekonomik durumunu incelemektedir. Bölge araştırmalarının bilim dünyasına getirdiği yeniliklerden biri de çok disiplinli olma özelliğinden kaynaklanan ve yukarıda belirtilen disiplinleşme sisteminde var olan üç ayrışım çizgisini ortadan kaldırarak farklı alanlardaki bilim adamlarını bir araya getirmesidir (Gulbenkian komisyonu,1995).

Günümüzde ise Sosyal Bilimler, özellikle bölge araştırmaları sırasında ortaya çıkan sonuçlar 1şı̆̆ında disiplinler arası çalışmalara yoğunlaşmıştır. Son yıllarda bilginin önlenemez çoğalışı Sosyal Bilimler alanındaki disiplinlerin kendi içinde bölünmelerine ve hatta farklı disiplinler arasında ara disiplinlerin oluşmasına sebep olmuştur. Sosyal bilimlerin gelişmesi ve sosyal bilimler alanında yeni çalışmaların ortaya çıkmasının sonucu olarak sosyal bilimler ile uğraşan sosyal bilimcilerin nasıl yetiştirilmesi gerektiği ve nitelikleri kendi de bir sosyal bilim olan eğitim bilimlerinin konusunu oluşturmuştur. 


\section{Karşılaştırmalı Ĕ̆itim ve Sosyal Bilimler Eğitiminin Durumu}

Varış (1988) Karşılaştırmalı Eğitimi, toplumlarda mevcut eğitim problemlerini ve bu problemleri doğuran nedenleri diğer toplumlarda benzer faktörlere değinerek saptayan, yorumlayan bir inceleme ve araştırma alanı olarak ortaya koyar.

Karşılaştırmalı Eğitim Bilimi, bir karşılaştırma araştırması oluştururken ölçüt olarak, Psikoloji, Sosyoloji ve Ekonomideki kuramlardan ve gerektiğinde istatistiksel verilerden yararlanır. Bunlar, "Olması Gerekli Olan Değerleri ” oluşturur. Bu ölçütler şekil.2 de gösterildiği üzere, eğitim alanında yapılan durum tespitlerinde olası aksaklıkları gösterir. “ Olan Değer" de, durum saptamaları yapılır. Yani karşılaştırmanın yapılması gereken alanlar, ülkeler arasında durum tespitiyle görünür hale getirilir. Karşılaştırmalı Eğitim Bilimi, karşılaştırmanın amacına göre araştırmalar için farklı yaklaşımlar sunar çünkü eğitim disiplinler arası bir alandır. Eğitim konusunda farklı politikaları, eğitimle ilgili yasaları, eğitimin finansal kaynakları ve yapılarını (ilköğretim, ortaöğretim yükseköğretim) inceler. Ayrıca amaç, içerik, yöntemler, araç-gereçler, öğretim materyalleri, değerlendirme, öğrenci, öğretmen, yönetici, veli, denetici ile ilgili tüm soruları inceler (Türkoğlu1998, 23).

Bilgi ve iletişim teknolojilerinin dünyayı hiç olmadığı kadar küçülttüğü bu dönemde, bilim adamlarının, eğitimcilerin fikirlerini ve başarılı uygulamaları paylaşmaları, ulusal ya da evrensel sorunlara ortak çözümler aramaları, kültürler ve sistemler arasında benzer ve farklı yönleri ortaya koyma çabaları sonucunda ortaya çıkan araştırmalar oldukça büyük bir öneme sahiptir. Buna göre eğitim sorunlarının çözümlenmesi için farklı ülkelerin eğitim sistemlerini incelemek, farklılıkları ve benzerlikleri saptamak, eğitim problemlerinin çözümü için farklı ülkelerin yaklaşımlarını incelemek yararlı görülmektedir. Karşılaştırmalı araştırma bir ya da daha fazla değişkenin farklılık ve/veya benzerliklerini görmek için aynı özelliğe sahip bir ya da daha fazla değişkenle karşılaştırılmasıdır.

Mikro anlamda yaklaşıldığında karşılaştırmalı araştırmalar iki değişkeni ya da ülkeyi ele alan çalışmalardır. Ülkeler mevcut problemlerin çözümü için farklı perspektiflere ihtiyaç duyarlar. Kendi problemlerini benzer özellikler taşıdığına inandıkları ya da sorun alanında başarılı gördükleri bir ülkeyi ve uygulamalarını inceleme ihtiyacı içinde olurlar.

İki ülkenin karşılaştırılmasında üç temel neden vardır:

- Ülkelerin kendi sistemlerini anlamak,

- Başka ülkelerle ilgili bilgileri genellemek,

- Kuram geliştirmeye katkıda bulunmak.

Yukarıda belirtilen üç hedef doğrultusunda iki veya daha fazla ülke arasındaki benzerlik ve farklılıkları ortaya koymak, mevcut modellerini tartışmak ve önerilerde bulunmak önemlidir (Kilimci, 2006).

Karşılaştırmalı eğitim alanında dünyada çok çeşitli araştırmalar yapılmıştır. Bu araştırmalar aşağıdaki alt başlıklar altında incelenecektir.

\section{Karşılaştırmalı Eğitimde Neler Karşılaştırılır?}

Araştırmacıların bir problemin çözümüne ilişkin farklı ülkelerdeki benzer ve farklı uygulamaları incelemesi uzun yıllar sürmüştür. Başarılı uygulamaların veya modellerin ithal edilmesi karşılaştırmalı eğitim literatürüne girmiş bir kavramdır (Phillips ve Ochs, 2004).

Karşılaştırmalı eğitim araştırmalarında, ülkelerin eğitim sistemleri, eğitimin yönetimi, belli bir kademeye ilişkin eğitim programları, belli bir derse ait öğretim programları, belli bir derse ait uygulanan öğretim yöntem ve değerlendirme teknikleri gibi birçok kavram çalışmaların amacını oluşturmaktadır. 
Karşılaştırmalı çalışmalarda dikkat edilmesi gereken en önemli unsurlardan biri de bir ülkede başarı ile uygulanan bir modelin ithal edilip, olduğu gibi yeni bir ülkeye aktarılmasıdır. Modelin ithal edildiği ülkenin şartlarının farklı olması ve başarıya yol açan etkenlerin farlılık göstermesi nedeniyle model aynı başarıyı gösteremeyebilir. Bu durumda başarıya yol açan etkenlerin tanımlanması gerekmektedir. Bu tanımlanma sonucu modeli örmek alan ülkenin mevcut şartları ışığında uygulanması daha fonksiyonel görünmektedir (Phillips ve Ochs, 2004).

\section{Karşılaştırmalı Araştırma Yaklaşımları Nelerdir?}

Karşılaştırmalı eğitim araştırmalarının geçmişi uzun yıllar öncesine kadar uzanmaktadır. Eski Yunanlılardan başlayıp on dokuzuncu yüzyıldan beri filozoflar, antropologlar, politikacılar ve sosyologlar tarafından kullanılan bir yaklaşımdır

Son zamanlarda karşılaştırmalı eğitim araştırmalarındaki eğilim değişmiştir. Karşılaştırmalı eğitim ve uluslararası eğitim çok disiplinli bir alan olmuş ve diğer disiplinlerin teori ve yöntemlerini de kullanan fakat kendi içinde ayırt edici bilgi, kavram ve özellikleri olan bir alan olmuştur (Hantrais,1995).

Karşılaştırmalı çalışmalardaki yaklaşımlara değinmeden önce bu alandaki modelleri kısaca tanımlamak faydalı olacaktır. Uluslararası karşılaştırmalı çalışmalar, farklı zamanlarda farklı modelleri de beraberinde getirmiştir. Bu modellerden ilki, karşılaştırmaların, benzer sebeplerin yol açtığı sosyal fenomenlerin tanımlanmasında ve gruplandırılmasında bir araç olarak kullanıldığ 1 "norma dayalı " modeldir. İkinci olarak da son yıllarda önem kazanan ve karşılaştırmaların, farklı kültürlerdeki kurumların, yapıların ya da sistemlerin daha derinlemesine analiz edilip bir ortalamasının alınmasını amaç edinildiği "içeriksel" modelidir. Son model ise; özellikle 1970 sonrası Sosyal Bilimlerde hızla yükselen disiplinler arası anlayışın, uluslararası iş birliğinin ve bilgi ağının egemen olmasının bir sonucu olarak ortaya çıkan ve özellikle Avrupa Birliği'ne üye ülkelerdeki sosyal ve ekonomik değişkenlerin gözlemlendiği, analiz edildiği “geniş ölçekli karşılaştırmalar" dır (Hantrais,1995).

Karşılaştırmalı araştırmalarda benimsenen yaklaşımlar Türkoğlu (1984), Saracoğlu (1990) ve Ültanır (2000)'e dayanarak aşağıda sunulmuştur.

Yatay Yaklaşım: Sistemlerin ayrı ayrı ve birlikte tüm unsurları incelenir. Bu unsurlar incelenirken araştırmanın yapıldığı döneme ait tüm unsurlar karşılaştırılır.

Farklı eğitim sistemlerinin ayrı ayrı unsurları paralel bir şekilde bir bütün olarak incelenir. Tüm değişkenler yan yana getirilerek farklılıklar saptanmaya çalışılır. Ayrıca karşılaştırılan boyut öğretim programı ise, programdaki tüm boyutların diğer programdaki boyutlarla karşılaştırılmasında da yatay yaklaşım kullanılmış olur .

Dikey Yaklaşım: İncelenen sistemin tarihi evrimi izlenir. Karşılaştırmalı eğitim yapan kişiyi geleceğe ait bazı tahminler yapmaya yöneltir.

Belirtilen bu yaklaşımlarımdan elde edilen bilgilerin de kullanıldığı Sosyal Bilimler öğretimi, dünyadaki güncel olan değişimleri de ele almasıyla anlam bulmaktadır Gelişmiş ülkeler örneğin A.B.D, sadece kendi sınırları içinde değil, dünyanın her yerinde yaşamını sürdürebilecek nitelikte bireyleri yetiştirmeyi hedeflemekte ve bu becerileri öğrencilere Sosyal Bilgiler öğretimi ile kazandırmaktadır (NCSS 2007). Tıpkı A.B.D' de olduğu gibi ortak değerler çerçevesinde bütünleşmek isteyen Avrupa Birliği'nde de “Ulusal Vatandaşlı̆̆ın" yanında "Avrupa Vatandaşlı̆̆ ${ }_{1}$ " becerileri de Sosyal Bilimler öğretimi ile gerçekleştirilmeye çalışılmaktadır. 
Avrupa Birliğine giriş sürecinde olan Türkiye'nin lise Sosyal Bilimler derslerinin evrensel değerler çerçevesinde ele alınıp değerlendirmesi, problemlerin çözümünde uluslararası bir yaklaşımın sergilenmesi ve Sosyal Bilimler öğretiminin ulusal boyutunun yanında evrensel boyutunun da ortaya konması önemli görülmektedir. Bu nedenle Türkiye'deki lise Sosyal Bilimler programlarının, Almanya, Fransa ve İngiltere gibi $\mathrm{AB}^{\prime}$ ye üye ülkeler ile A.B.D.de uygulanan programlarla karşılaştırılması, küreselleşen dünyadaki çalışmaların, uygulamaların paylaşılması ve başarılı örneklerin öne çıkarılması eğilimi düşünüldüğünde önemli görülmektedir.

\section{Yöntem}

Bu araştırma ile Almanya, A.B.D., Fransa, İngiltere ve Türkiye'deki lise Sosyal Bilimler programlarının karşılaştırılmasını hedeflenmiştir.

\section{Araştırmanın Modeli}

Bu çalışma, konusu gereği ülkeler arası (cross national) karşılaştırmalı eğitim araştırmasıdır. Doküman analizi yoluyla nitel araştırma yönteminin kullanıldığ 1 bu çalışmada, incelenen ülkelerin lise Sosyal Bilimler programlarında araştırma soruları çerçevesinde tüm değişkenler yan yana getirilerek, aralarındaki benzerlik ve farklılıklar saptanmıştır. Almanya, A.B.D., Fransa, İngiltere ve Türkiye'de genel lise Sosyal Bilimler programlarının amaç, içerik, süreç ve değerlendirme yöntemlerinin karşılaştırılmasında yatay yaklaşım kullanılmıştır.

Bu çalışma A.B.D Nebraska eyaleti ile İngiltere, Fransa ve Almanya'daki Lise Sosyal Bilimler programları ve Türkiye'deki lise Sosyal Bilimler programlarını kapsamaktadır. Çalışmada bu ülkelerin seçiminde esas alınan kriterler ise aşağıda sunulmuştur;

1- A.B.D' nin dünyada, İngiltere, Fransa ve Almanya'nın da AB içerisinde sahip oldukları ekonomik ve siyasal gücün eğitim alanına yansıyan etki alanı (geniş etkiye sahip eğitim sitemleri)

2- Sözü edilen ülkelerin Sosyal Bilimler araştırmalarına olan katkı oranlarının yüksekliği: Tonta ve İlhan(1997) yaptıkları çalışmada 1985-1996 yılları arasında Social Science Citation Index'te (SSCI) dizinlenen dergilerde yayınlanan Türkiye adresli yayınları incelemişler ve bu süre içerisinde ilgili dergilerde Türkiye adresli toplam 887 yayının yer aldığını ortaya koymuşlardır. Tonta ve İlhan ayrıca 1996 yılında yayınlanan ve SSCI'de dizinlenen Türkiye adresli bilimsel yayınların sayısının ise 166 olduğunu ve bu sayıyla Türkiye'nin 1996 yılında toplam Sosyal Bilimler yayınlarının \%0,14'ünü üretmiş olduğunu ve dünya sıralamasında 34. sırada yer aldığını da ortaya koymuşlardır. A.B.D, İngiltere, Fransa ve Almanya'nın aynı alandaki istatistikleri aşağıda sunulmaktadır.

Tablo 1. 1996 Yılında Sosyal Bilimler Alanındaki Yayın Sayılarına Göre Ülkeler Sıralaması

\begin{tabular}{|c|c|c|}
\hline Sira No & Ülke & Yayın Say1S1 \\
\hline 1 & ABD & 69.574 \\
\hline 2 & İngiltere & 15292 \\
\hline 5 & Almanya & 4162 \\
\hline 9 & Fransa & 2710 \\
\hline
\end{tabular}


$34 \quad$ Türkiye

177

Kaynak: http://yunus.hun.edu.tr/ tonta/yayinlar/sscipaper.html

3- Endüstrileşme sonrası ortaya çıkan bilgi-temelli toplum modelinde bu dört ülkenin, diğer ülkelere göre daha fazla tecrübeye sahip olmalarıdır.

\section{Verilerin Toplanması}

$\mathrm{Bu}$ araştırmada nitel araştırma yöntemlerinden doküman incelemesi kullanılarak veriler toplanmıştır. Doküman incelemesi, araştırılması hedeflenen olgu veya olgular hakkında bilgi içeren yazılı materyallerin analizidir (Yıldırım ve Şimşek, 2005).

Çalışmaya temel oluşturacak dokümanlara konu ile ilgili alan yazın taranması ile günümüz dünyasında bilgiye ulaşımın en hızlı yolu olan internet ortamından ulaşılmıştır. İngiltere, Fransa ve Almanya Ulusal Eğitim Bakanlıkları ile elektronik posta yoluyla temasa geçilmiş, Sosyal Bilimler programlarına ulaşılmıştır. Diğer taraftan Almanya, A.B.D., Fransa, İngiltere ve Türkiye'de Sosyal Bilimler eğitimi ile ilgili hazırlanan tez, kitap, dergi, makale gibi basılı bilimsel kaynaklardan yararlanılmıştır. Ayrıca, adı geçen ülkelerdeki Sosyal Bilimler programları ile ilgili web sayfalarına, yasa ve mevzuata ulaşılmıştır.

ABD'nin birçok eyaletinde olduğu gibi Nebraska eyaletindeki liselerin haftalık ders saatlerini gösteren çizelgenin de ders kredileri baz alınarak yapılması ve kredi sisteminin diğer ülkelere göre farklılık göstermesi nedeni ile Nebraska Cozad Lisesi'nden (Cozad High School) James Terry (Sosyal Bilgiler öğretmeni) ile iletişime geçilmiş ve sınıflara göre haftalık ders saatlerine ulaşılmıştır.

Çalışmanın iç geçerliliğinin yükseltilmesi için toplanan veriler uzman incelemesine tabi tutulmuştur. Bunun üçün Sosyal Bilimler/Bilgiler öğretimi alanında görev yapan 3 öğretim üyesine ve özellikle nitel araştırma konusunda uzmanlaçmı.2 öğretim üyesine çalışma farklı boyutları ile inceletilmiş ve sağladıkları dönütler doğrultusunda düzenlemeye gidilmiştir. Diğer taraftan ulaşılan programların halen yürürlükte olup olmadığının kontrolü bakanlıklara yollanan elektronik postalar aracılığı ile yapılmış ve katılımcı teyidi de sağlanmıştır.

Çalışmaya dış geçerlik açısından bakıldığında incelenen ülkelerin programların başka ülkelerle karşılaştırma yapmaya ve istenen düzeyde bilgilerin ulaşılmasına el verecek kadar detaylı olduğu sonucuna varılmıştır

\section{Verilerin Analizi}

Bu çalışmada temel olarak nitel araştırma yöntemi kullanılmıştır. Araştırma için elde edilen veriler amaçlar doğrultusunda karşılaştırılmıştır. Karşılaştırmalı eğitimin kendine özgü analiz yöntemlerine uygun olarak benzerlik ve farklılıklar analiz edilmiştir. Araştırma sorularından yola çıkarak veri analizi için bir çerçeve oluşturulmuştur. Bu çerçeveye göre veriler seçilmiş, düzenlenmiş, benzerlikler ve farklılıklar bir araya getirilmiş, karşılaştırılmış ve yorumlanmıştır. Çalışmada ele alınan ülkelerin lise Sosyal Bilimler programları orijinallerine bağlı kalınarak ilgili dillerden Türkçe 'ye çevrilmiştir. A.B.D ve İngiltere programları araştırmacının kendisi tarafından Türkçe 'ye çevrilirken, Almanya ve Fransa'ya ait programlar uzman çevirmenler tarafından Türkçeleştirilmiştir.

Almanya'dan elde edilen kaynaklar Almanca, Fransa'dan elde edilen kaynaklar Fransızca olduğu için elde edilen kaynaklar bu konuda eğitimci uzman olan kişiler tarafından Türkçe 
'ye çevrilmiş, bu çevirilerin güvenilirliğinin anlaşılması için çevirileri yapılan bu dokümanlar systran (online web çevirici) programı ile İngilizce'ye çevrilip araştırmacı tarafından doğruluğu teyit edilmiştir. Yapılan inceleme sonucunda genel olarak çevirilerin doğru olduğu kanaatine varılmıştır. İngiltere ile A.B.D ile ilgili dokümanların Türkçeleştirilmesi araştırmacı tarafından yapılmıştır. Çalışmaya Fransa'daki lise Sosyal Bilimler programları, A.B.D” den "Nebraska eyaletinde uygulanan Sosyal Bilgiler Programı", İngiltere'den Bedford Sixth Form College kurumunun "Advanced (A)" ile "Advanced Subsdiary (AS)"siniflarının programları ile Almanya'dan Hamburg eyaletinin "Gymnasium Oberstufe" okullarının Sosyal Bilimler programları dahil edilmiştir. Türkiye'den ise genel liselerdeki mevcut olan bölümlerin (Sosyal Bilimler, Türkçe-Matematik, Fen Bilimleri ve Yabancı Diller) programları çalışma kapsamına alınmıştır. Tüm veriler analiz edilip karşılaştırmalar yapıldıktan sonra Türkiye'deki lise Sosyal Bilimler programı için bir model önerisinde bulunulmuştur.

\section{Bulgular}

Bu bölümde literatürün taranması ile çalışmanın örneklemini oluşturan ülkelerin lise Sosyal Bilimler programlarından elde edilen bulgular ele alınmış ve yorumlanmıştır. Çalışmaya konu olan ülkelerin yetiştirmeyi planladıkları birey profilleri eğitim sisteminin genel amaçlarında kendini göstermektedir. Tablo 1. Sözü edilen ülkelerin hangi becerilerle donanmış bireyler yetiştirmeyi amaçladıklarını göstermektedir.

Tablo 2. Çalışmada Ele Alınan Ülkelerin Eğitimdeki Genel Amaçları

\begin{tabular}{|l|l|}
\hline Ülkeler & \multicolumn{1}{c|}{ Genel Amaçlar } \\
\hline Almanya & $\begin{array}{l}\text { Herkese eşit haklar sağlayarak, kişinin ilgi ve } \\
\text { yeteneklerini teşvik etmek ve geliştirme talebine cevap } \\
\text { verecek, kişisel, mesleki ve sosyal yaşantısını } \\
\text { biçimlendirmesini sağlamak }\end{array}$ \\
\hline A.B.D. & $\begin{array}{l}\text { Öğrencilerin Entelektüel gelişmelerini sağlayarak mevcut } \\
\text { potansiyellerini geliştirmek; mesleki beceriler } \\
\text { kazandırmak ve Amerikan demokrasisini içselleştirmiş } \\
\text { etkin vatandaşlar yetiştirmek }\end{array}$ \\
\hline Fransa & $\begin{array}{l}\text { Öğrencilere bilişsel ve devinimsel gelişimi sağlayacak } \\
\text { bilgiler vererek onların bulundukları ortama uyumu } \\
\text { kolaylaştırmak; diğer insanların fikirlerine saygı duymayı } \\
\text { öğretmek, Ülkenin değerlerini korumak ve değişen } \\
\text { dünyaya hazırlamak }\end{array}$ \\
\hline İngiltere & $\begin{array}{l}\text { Her çocuğun yeteneği ve ilgisine uygun eğitim almasını } \\
\text { sağlamak }\end{array}$ \\
\hline Türkiye & $\begin{array}{l}\text { Atatürk ilkelerine bağlı; Türk milletinin değerlerini } \\
\text { koruyup geliştiren, insan haklarına saygıll, demokratik ve } \\
\text { laik yurttaşlar yetiştirmek; hür ve bilimsel düşünme } \\
\text { gücüne, geniş bir dünya görüşün sahip, topluma karşı } \\
\text { sorumluluk sahibi, yapı̀ı ve yaratıcı bireyler yetiştirmek; } \\
\text { Türk milletini çağdaş dünyanın seçkin bir ortağı yapmak. }\end{array}$ \\
\hline
\end{tabular}


Tablo 2 incelendiğinde Türkiye için ortaya çıkan sonuçlar şöyledir; Bireyin ilgi ve yetenekleri doğrultusunda yaratıcılı̆̆ının geliştirilmesi, İnsan haklarına saygılı demokratik kişiliğe sahip bireyler yetiştirilmesi, Sorumluluk sahibi, bağımsız tutum geliştirebilen yapıcı, yaratıcı, sorun çözebilen bireyler yetiştirilmesi Almanya ve A.B.D ile ortak noktalarda buluşmaktadır. Kültürel ve ahlaki değerlerin korunması ve geliştirmesi amacı Fransa ile benzerlik göstermektedir. Diğer taraftan hür ve bilimsel düşünme gücüne sahip olma amacı sadece Türk Milli Eğitiminin genel amaçlarında yer almaktadır.

Tablo 2 de belirtildiği şekilde genel amaçlara sahip olan bu ülkelerde eğitim yönetimi de farklılıklar göstermektedir. Şöyle ki; Fransa, İngiltere ve Türkiye'de Milli Eğitim Bakanlıkları eğitim alanındaki kararların alınmasında tek yetkili olarak görülmektedir. Programların hazırlanmasından, öğretmenlerin atanmasına kadar birçok konuda tek söz sahibi konumundadır. Bu ülkelerde eyalet sistemi geçerli olduğundan eğitimdeki harcamalardan, programların hazırlanıp uygulanmasına kadar birçok konudaki karar eyaletlerdeki eğitim birimleri tarafından alınmaktadır. Eyaletler farklı programları uygulama haklarına sahiptir. Ulusal anlamda bir program yoktur. Zorunlu eğitim bir öğrencinin yasalarca belirlenmiş süre içinde, formal eğitim kurumlarında bulunması ve eğitim alması sorumluluğunu içeren bir terimdir. Çalışmaya bir boyutu ile konu olan lise eğitimi bu ülkelerin bazılarında zorunlu eğitim içinde yer alırken, bazıların da zorunlu eğitim sonrası dönemde ele alınmaktadır. Bu açıdan bakıldığında Türkiye bu süre açısından en kısa döneme sahip olan ülkedir. Amerika Birleşik Devletleri ve Almanya'da 12, İngiltere'de 11, Fransa'da 10 y1l zorunlu eğitim süresi Türkiye'de 8 yıldır.

Türkiye ve İngiltere'de lise eğitimi zorunlu eğitim süresinin dışında bırakılmıştır. İngiltere'de zorunlu eğitimi bitiren öğrenciler Sixth Form ya da Further Education College (İleri Eğitim Koleji) denilen Türkiye'deki liselere denk düşen eğitim kurumlarına gitmektedir. Amerika Birleşik Devletleri, Almanya ve Fransa da ise lise eğitimi zorunlu eğitim süresinin içinde yer almaktadır. Lise eğitimine devam eden öğrenci sayılarına bakıldığında ise Amerika Birleşik Devletleri çalışma kapsamındaki ülkeler arasında ilk sıradadır. İngiltere ikinci, Türkiye üçüncü, Almanya dördüncü, Fransa ise beşinci sıradadır Liseye devam eden öğrenci sayılarında ilk sırada yer alan Amerika Birleşik Devletleri öğrencilerin ortaöğretimi bitirme oranlarında \% 73’lük oranla 3. sırada yer almaktadır. Almanya \%93'lük oranla çalışma kapsamındaki ülkeler arasında ilk sırada yer almakta ve ortaöğretime aldığı öğrencileri sistemde tutma ve mezun etmede oldukça başarılı görünmektedir. Türkiye ise ortaöğretimden öğrenci mezun etme oranlarında \%55 lik düşük bir orana sahiptir (http://www.sprc.pt/upload/File/pdf/ Öğrencilerin toplumun sorunlarını bilen ve ülkenin sosyal, kültürel ve ekonomik yönlerden kalkınmasına katkıda bulunan bireyler olarak yetiştirme misyonunu yüklenen lise eğitiminde, Sosyal Bilimler dersleri bu misyonu hayata geçirmede büyük bir öneme sahiptir. Lise programlarına dahil edilen her bir Sosyal Bilimler dersi o ülkedeki toplumsal ve kültürel ihtiyacın bir yansımasıdır.

Her ülke ihtiyacı ve öncelikleri doğrultusunda Sosyal Bilimler derslerini lise programlarına dahil ederler. Ülkelerin ihtiyaç ve öncelikleri farklı olduğundan lise programlarına konulan dersler de farklılaşmaktadır. 
Tablo 3 Almanya, A.B.D., Fransa, İngiltere ve Türkiye' deki Genel Liselerde Verilen Sosyal Bilimler Dersleri

\begin{tabular}{|l|c|c|c|c|c|}
\hline Dersler/Ülkeler & Alm. & A.B.D. & Fransa & İng. & Tür. \\
\hline Tarih & $\mathbf{x}$ & $\mathbf{x}$ & $\mathbf{x}$ & $\mathbf{x}$ & $\mathbf{x}$ \\
\hline Coğrafya & & $\mathbf{x}$ & $\mathbf{x}$ & $\mathbf{x}$ & $\mathbf{x}$ \\
\hline Vatandaşlık & & $\mathbf{x}$ & $\mathbf{x}$ & $\mathbf{x}$ & \\
\hline Felsefe & & $\mathbf{x}$ & & & $\mathbf{x}$ \\
\hline Sosyoloji & & $\mathbf{x}$ & & & $\mathbf{x}$ \\
\hline Psikoloji & & $\mathbf{x}$ & $\mathbf{x}$ & $\mathbf{x}$ & $\mathbf{x}$ \\
\hline Ekonomi & $\mathbf{x}$ & & & $\mathbf{x}$ & $\mathbf{x}$ \\
\hline Din & $\mathbf{x}$ & & & & $\mathbf{x}$ \\
\hline Turizm & & & & & $\mathbf{x}$ \\
\hline İnsan İlişkileri & & & & & $\mathbf{x}$ \\
\hline Trafik Bilgisi & & & & & $\mathbf{x}$ \\
\hline Mantık & & & & & $\mathbf{x}$ \\
\hline T.C İnkılap Tar. & & & & $\mathbf{5}$ & $\mathbf{1 3}$ \\
\hline Çağ. Türk Tar. & & $\mathbf{6}$ & $\mathbf{4}$ & & \\
\hline Milli Güvenlik & & & & & \\
\hline Toplam & $\mathbf{3}$ & & & & \\
\hline
\end{tabular}

http://www.scotuscc.org/socialscience.html

http://www.bedfordschool.org.uk/upload docs/AcademicCurriculumSept06.pdf

http://www.berufskolleg-eifel.de/html/wirtschaftsgymnasium.html

http://www.lauregatet.fr/article.php3?id article $=38$

http://ogm.meb.gov.tr/

Tablo 3 incelendiğinde görülmektedir ki; Almanya, Fransa, İngiltere ve Amerika Birleşik Devletleri'nde liselerde okutulan Sosyal Bilim dersleri büyük bir fark göstermemektedir. Tarih dersi tüm ülkelerin lise Sosyal Bilimler programlarında yer alırken, Coğrafya dersi sadece Almanya' daki lise programında yer almamaktadır. Ekonomi dersi Türkiye dışındaki dört ülkede okutulmaktadır. Din dersi Almanya, İngiltere ve Türkiye' de zorunlu ders statüsünde verilmektedir. Sosyoloji, Psikoloji gibi dersler lise programlarında seçmeli statüsünde yer alırken, Amerika Birleşik Devletleri'nde ise "modern programlar" adıyla anılan programlarda yer almaktadırlar.

\section{Almanya 'da Lise Sosyal Bilimler Derslerinin Dağılımı}

Almanya da genel lise eğitiminde farklı okul tipleri mevcuttur. Bunların içinde Gymnasium adı verilen okullar başarılı öğrencilerin eğitim gördüğü ve bu çalışmada genel eğitim veren liseler olarak kabul edilmiş okullardır. İlköğretimi başarı ile bitiren her öğrenci, bu okullara kaydını yaptırabilir. Gymnasium'ların 5. 10. sınıfları ortaöğretimin ilk bölümünü (Sekundarbereich) oluştururken, 11.ile 13. sınıfları ortaöğretimin ikinci (ABİTUR) bölümünü oluşturmaktadır. Tarih, Ekonomi, Bilişim ve Enformatik, Sosyal ve Politik Bilimler dersleri Almanya'da genel liselerde (Gymnasium) okutulan Sosyal Bilimler dersleridir. Sözü edilen bu derslerin haftalık dağılımı aşağıdaki tabloda sunulmuştur 
Tablo 4. Almanya' da Genel Liselerdeki Örnek

\begin{tabular}{|c|c|c|c|}
\hline $\begin{array}{c}\text { Sosyal Bilimler } \\
\text { Dersleri }\end{array}$ & 11.sınıf & 12. Sinıf & 13. Sınıf \\
\hline Tarih & 2 Saat & 2 Saat & 1 Saat \\
\hline $\begin{array}{c}\text { Politik } \\
\text { Ekonomi }\end{array}$ & 2 Saat & 2 Saat & 2 Saat \\
\hline Din ve Etik & 2 Saat & 2 Saat & 2 Saat \\
\hline Toplam & 6 Saat & 6 Saat & 5 Saat \\
\hline
\end{tabular}

Kaynak:http://cdl.niedersachsen.de/blob/images/C12621825_L20.pdf

Gymanasium Oberstufe denilen ve Türkiye'deki genel liselere denk düşen okullarda öğrenciler 11.- 13. sınıflarda eğitim alırlar. Bu okullardaki Sosyal Bilimler derslerinin haftalık dağılımına baktığımızda; 11. Sınıfta Tarih dersinin 2, Din ve Felsefe dersinin 2, Politik Ekonomi dersinin 2, 12. sınıfta; Tarih, Politik Ekonomi, Din derslerinin 2 'şer saat, 13. Sınıfta ise Tarih, derslerinin 1'er saat, diğer derslerin 2' şer saat okutulduğunu görmekteyiz

\section{Amerika Birleşik Devletleri'nin (Nebraska Eyaleti) Lise Sosyal Bilimler Dersleri}

Amerika Birleşik Devletleri'nde hakim olan eyalet sistemi gereği, eyaletler arasında farklar bulunmaktadır. Hatta belirli bir eyalet içinde bile farklılıklar mevcuttur. Bu farklılıklar liselerin uyguladıkları eğitim programlarına da yansımaktadır. Liselerin eğitim programlarına yansıyan en büyük farklılık bazılarının klasik, bazılarının da modern olarak adlandırılan programları uygulamalarıdır. Klasik lise Sosyal Bilimler programında Dünya Tarihi, Amerikan Tarihi, Coğrafya ve Modern Dünya Sorunları (Güncel Olaylar), Vatandaşlık, Çağdaş Amerikan Hükümeti ve Ekonomi dersleri mevcuttur. Daha önce de değinildiği gibi modern Sosyal Bilimler programında klasik programdaki Sosyal Bilimler derslerine ek olarak Sosyoloji, Psikoloji gibi "Supporting Complementary Subject Areas" adı verilen ve klasik programı tamamlayıcı ve destekleyici dersler de yer almaktadır.

Tablo 5. Amerika Birleşik Devletleri'nde (Nebraska) Klasik ve Modern Programlara Göre Sosyal Bilimler Derslerinin Dağılımı

\begin{tabular}{|l|c|c|}
\hline Dersler & Klasik Program & Modern Prohram \\
\hline Dünya Tarihi & $\mathrm{X}$ & $\mathrm{X}$ \\
\hline Coğrafya & $\mathrm{X}$ & $\mathrm{X}$ \\
\hline Amerikan Tarihi & $\mathrm{X}$ & $\mathrm{X}$ \\
\hline Psikoloji & $\mathrm{X}$ & $\mathrm{X}$ (seçmeli) \\
\hline Sosyoloji & & $\mathrm{X}$ (seçmeli) \\
\hline Güncel Olaylar & $\mathrm{X}$ & $\mathrm{X}$ \\
\hline Vatandaşlık & $\mathrm{X}$ & $\mathrm{X}$ \\
\hline Çağdaş Amerikan Yönetimi & & $\mathrm{X}$ \\
\hline Modern Dünya Sorunları & & \\
\hline
\end{tabular}

Kaynak:http://www.scotuscc.org/socialscience.html.

Sözü edilen bu farklılıklar NCSS'in Sosyal Bilgiler öğretiminde okullara önerdiği modelle en aza inmiş durumdadır. Bundan dolayı birçok eyaletin Sosyal Bilgiler programı birbirine 
benzer hale gelmiştir. Bu nedenle de Nebraska eyaletinin Sosyal Bilgiler programı araştırma için seçilmiş ve incelenmiştir.

\section{Fransa'da Lise Sosyal Bilimler Derslerinin Alanlara Göre Dă̆ılımı}

Fransa'daki lise eğitiminde Türkiye' de olduğu gibi bölümleşme mevcuttur. Bunlar Edebiyat Bölümü (L), Ekonomi Bölümü (ES) ve Fen Bilimleri (S) Bölümleridir. Bu bölümlere katılacak öğrencilerin tespiti 11. sınıfta yapılmaktadır. Liselerin 10. sınıfında bölümlere ayrılma yoktur. Öğrenciler ortak dersler almaktadır. Ana dersler ve zorunlu seçimlik adı verilen gruptan, öğrenciler, Tarih, Coğrafya, Ekonomi ve Sanat Tarihi derslerini görmektedirler. Sosyal Bilimler içinde kabul edilmeyen anadil ve yabancı dil dersleri de bu sinıfta ağırlıklı biçimde ele alınmaktadır. 11. sınıfta ise Edebiyat Bölümündeki öğrenciler Tarih - Coğrafya dersi ile Vatandaşlık dersini ana ders statüsünde almaktadır. Bu alandaki öğrenciler Sanat Tarihi dersini ise zorunlu seçimlik olarak görmektedir. Ulusal ve yabancı dil dersleri yine bu sinıfta gerek ana dersler gerek zorunlu seçimlik grubu gerekse de seçmeli dersler grubunda yer almaktadır. Aynı sınıfın Ekonomi Bölümündeki öğrenciler ise Ekonomi ,Tarih ve Coğrafya derslerini ana dersler statüsünde alırken Sanat Tarihi dersini ise zorunlu seçimlik grubundan almaktadır. Dil dersleri yoğun olarak bu bölümde de verilmektedir. Fen Bilimleri bölümündeki öğrenciler de Sosyal Bilimler derslerinden sadece Tarih ve Coğrafyayı görmektedir (http://www.lauregatet.fr/1mg/doc/doc/plaquatte_serie_es- 2-2.doc).

Lise eğitiminde son sınıf olarak kabul edilen 12. sınıfın Edebiyat bölümündeki öğrenciler; Tarih, Coğrafya, Vatandaşlık ve Felsefe derslerini ana dersler statüsünde görmektedirler. .Aynı sınıfın Ekonomi bölümünde Ekonomi, Tarih ve Coğrafya dersleri vardır. Tamamlayıcı ders statüsünde ise Politik Bilimler dersi mevcuttur. Son sınıfın Fen Bilimleri bölümünde ise sadece Sanat Tarihi dersi seçmeli ders statüsünde öğretilmektedir (http://www.lauregatet.fr/img/doc/plaquatte_serie_es-2-2.doc).

Fransa'daki liselerde okutulan Sosyal Bilimler derslerinin bölümlere göre dağılımını inceledikten sonra, bu derslerin bölümlere ve statülerine göre haftalık dağılımına bakmakta fayda vardir.

Grafik 1. Fransa'da Lise Sosyal Bilimler Derslerinin Bölümlere Göre Dağılımı

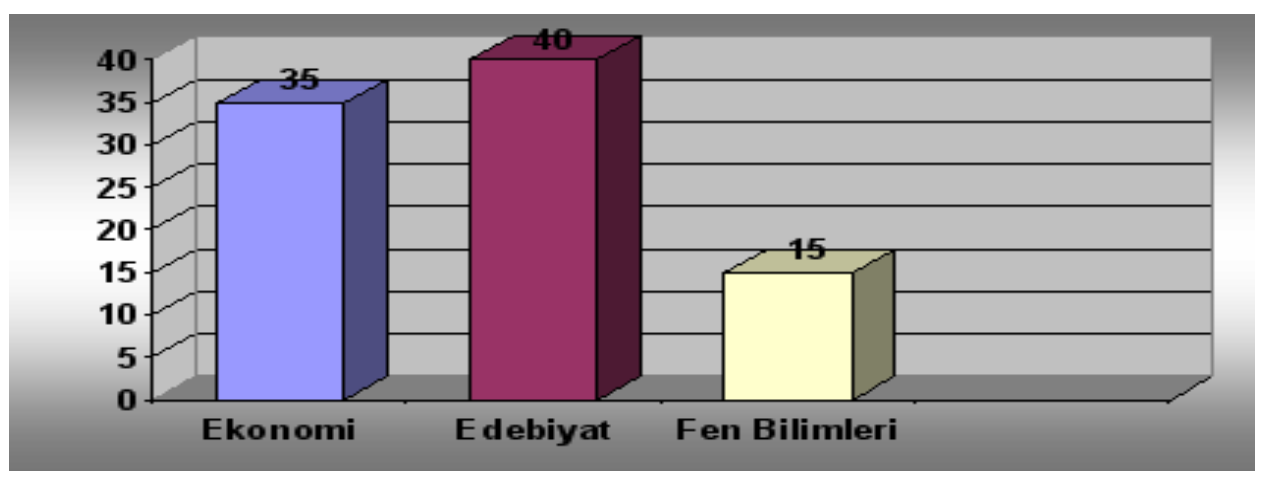

http://www.lauregatet.fr/article.php3?id_article=38

http://www.lauregatet.fr/IMG/doc/PLAQUETTE_SERIE_ES-2-2.doc

http://www.lauregatet.fr/article.php3?id_article=36

Grafik 1'in de gösterdiği gibi Fransa'da Sosyal Bilimler derslerinin tüm derslere göre oranı incelenen diğer dört ülkeye göre oldukça yüksek bir orana sahiptir. Fransa'da liselerde 
Sosyal Bilimler derslerinin sayısı az olsa da haftalık ders saatleri ele alındığında bu derslere fazla saat ayrıldığı gözlemlenmektedir. Bu durumda Sosyal Bilimler derslerinin tüm dersler içindeki oranını yükseltmektedir. Sosyal Bilimler dersleri Edebiyat Bölümü programlarında tüm derslerin \%40 lik oranına sahipken, Ekonomi Bölümü programında bu oran \%35'tir. Fen Bilimleri programında ise Sosyal Bilimler derslerinin oranı tüm dersler içinde \%15'tir.

\section{Ingiltere'de Lise Sosyal Bilimler Grubu Derslerinin Dă̆ılımı}

İngiltere' de genel lise eğitimi iki yıl sürmektedir. Bu iki yıl içinde öğrenciler uzmanlaşmak istedikleri ve üniversite eğitimlerinde seçmeyi planladıkları alanda dersler görmektedir. Durumun böyle olması nedeniyle diğer ülkelerde zorunlu ders statüsünde okutulan Sosyal Bilimler dersleri İngiltere'de seçimlik statüsünde ele alınmaktadır. İngiltere'de genel liselerde öğrencilere sunulan ve uzmanlaşmak istedikleri alanda işlerine yarayacak bir dizi ders vardir (Eurybase 2007).

Sixth Form olarak adlandırılan genel liselerde öğrencilerin seçebilecekleri AS Level ve A Level düzeyinde dersler mevcuttur. İngiltere' de lise öğrencilerinin seçebilecekleri bu dersler içinde Tarih, Coğrafya, Ekonomi ve Din dersinden oluşan Sosyal Bilimler Modülü bulunmaktadır. 12.Sınıfta (Lower Sixth Form) öğrenciler derslerini seçtikleri dört modülden birini Sosyal Bilimler Modülü oluşturmaktadır. Seçilen bu derslerin her biri haftalık 8 saat okutulurken, 13.Sınıfta (Upper Sixth Form) seçilen ders sayısı dörtten üçe düşmekte ve haftalık ders saati her ders için 9 olmaktadır

AS Level'deki öğrenciler seçtikleri 4 dersi haftada 8'şer saatten toplam 32 saat görmektedir. $\mathrm{Bu}$ öğrencilere haftada 6 saat kendi gelişimleri doğrultusunda çalışma imkanı sunulmaktadır. Haftada bir saat ise, öğrencilere dahil oldukları program içinde zamanlarını ve çalışmalarını etkili bir biçimde kullanma becerilerini geliştirmeleri için öneriler sunulmaktadır. AS Level Haftalık 39 saatlik bir öğretim zamanını hayata geçirmektedir (http://www.bedfordschool.org.uk/upload docs/Academic Curriculumsept06.pdf).

Lise 9. sinıfta öğrenciler zorunlu olarak Coğrafya, Tarih, Sağlık Bilgisi ve Din Kültürü derslerini görmektedir. Bu dersler alan fark etmeksizin tüm öğrencilere verilmektedir. Ortak ve zorunlu statüsünde olan bu derslerin toplamı haftalık 7 saat olup, toplam 30 saat ders yükünün \%25 ünü oluşturmaktadır (http://ogm.meb.gov.tr/).

Lise 10. Sınıfta ise, öğrenciler Sosyal Bilimler derslerini alanlarının ağırlıklarına göre almaktadır. Sosyal Bilimler alanında Tarih ve Coğrafya dersi 4 , Psikoloji dersi ise 2 saat olarak "Alan dersi" statüsünde verilmektedir. Din Kültürü Ahlak Bilgisi ile Milli Güvenlik dersi 1'er saatlik "ortak ders" olarak okutulmaktadır. Toplam 12 saat Sosyal Bilimler derslerine ayrılırken, bu oran, seçmeli dersler hariç haftalık ders yükünün \%33'nü oluşturmaktadır (http://ogm.meb.gov.tr/).

10. Sınıf "Fen Bilimleri" alanında, öğrenciler Coğrafya ile Tarih derslerini 2'şer saat olarak ortak dersler statüsünde görmektedir. Din Kültürü Ahlak dersi ile Milli Güvenlik dersi ise 1'er saat ortak ders olarak öğretilmektedir. 10. sınıf Fen Bilimleri alanında seçmeli dersler hariç, haftalık 6 saat Sosyal Bilimler derslerine ayrılmaktadır. Toplam dersler içindeki oranı \%16 dir (http://ogm.meb.gov.tr/).

10. sınıfın "Türkçe Matematik" alanında ise, Coğrafya 4 saat, alan dersi olarak verilirken, Tarih 2 saat olarak ortak dersler içinde yer almaktadır. Ayrıca Din Kültürü Ahlak Bilgisi ile Milli Güvenlik dersleri 1'er saat ile diğer ortak dersler olarak bu alanda karşımıza çıkmaktadır. Türkçe Matematik alanında seçimlik dersler hariç, haftalık 8 saat Sosyal 
Bilimlere ayrılmaktadır. Bu da toplam ders saatinin yaklaşık \%25'ine karşılık gelmektedir (http://ogm.meb.gov.tr/).

10. Sınıfın "Yabancı Dil" alanında ise Sosyal Bilimler dersleri şöyle bir dağılım göstermektedir. Tarih ve Coğrafya Dersi 2' şer saat ortak ders statüsünde okutulurken, Din Kültürü ve Ahlak Bilgisi ve Milli Güvenlik 1 saat olarak yine ortak ders olarak verilmektedir. Sosyal Bilimler derslerinin toplam 5 saat ile en düşük olduğu alan Yabancı Diller alanıdır. Toplam haftalık ders saati baz alındığında \%16'lı bir orana sahiptir (http://ogm.meb.gov.tr).

Lise'nin 3. sınıfı yani 11. Sınıfta "Sosyal Bilimler " alanında öğrenciler, Felsefe (2 saat), Din Kültürü Ahlak (1 saat), T.C İnkılap Tarihi (2 saat) ve Trafik (1 saat) derslerini ortak dersler statüsünde almaktadır. Alan dersleri olarak da Tarih (4 saat), Coğrafya(4 saat) ve Sosyoloji (2 saat) dersleri verilmektedir. Sosyal Bilimler derslerinin toplamı seçmeli dersler hariç, 16 saat olup tüm derslerin oranının yarısı kadardır \%50 (http://ogm.meb.gov.tr/).

Aynı sınıfın "Fen Bilimleri” alanında ise, Felsefe (2 saat), Din Kültürü Ahlak (1 saat), T.C İnkılap Tarihi (2 saat), Trafik (1 saat) ortak dersler olarak öğretilmektedir. Alan dersleri olarak hiçbir Sosyal Bilimler dersi bu alanda okutulmamaktadır. Bu alandaki öğrenciler ancak seçimlik dersler vasıtasıyla Sosyal Bilimler derslerini alabilmektedir. Bu alanda Sosyal Bilimler dersleri toplam ders saati içinde 1/5 lik bir orana sahiptir (http://ogm.meb.gov.tr/).

"Türkçe Matematik" alanında öğrenciler, Felsefe (2 saat), Din Kültürü Ahlak (1 saat), T.C İnkılap Tarihi (2 saat), Trafik (1 saat) derslerini ortak ders statüsünde almaktadır. Alan dersi olarak da sadece Coğrafya (2 saat) dersini almaktadırlar. Bu alanda Sosyal Bilimler derslerine haftada 8 saat ayrılmıştır. Sosyal bilimler derslerinin diğer derslere göre oranı \%25'tir (http://ogm.meb.gov.tr/).

11.Sınıf "Yabancı Dil” alanında ise, öğrencilere, Felsefe (2 saat), Din Kültürü Ahlak (1 saat), T.C İnkılap Tarihi (2 saat), Trafik (1 saat) dersleri ortak ders statüsünde verilmektedir. Alan dersi olarak da Coğrafya (2 saat) verilmektedir. Haftalık ders saati ele alındığında, 8 saatin Sosyal Bilimler derslerine ayrıldığı görülmektedir. Sosyal bilimler derslerinin diğer derslere göre oran1 \%25'tir (http://ogm.meb.gov.tr/).

12. sinıfta; "Sosyal Bilimler" alanında, Din Kültürü Ahlak dersinin (1 saat) ortak ders statüsünde verildiği görülmektedir. Bu alandaki öğrenciler, alan dersleri olarak; Coğrafya (4 saat) , Çağdaş Dünya Tarihi (4 saat), Mantık (2 saat) derslerini görmektedir. 11 saatlik Sosyal Bilimler dersleri toplam derslerin \%33' üne karşılık gelmektedir (http://ogm.meb.gov.tr/).

"Fen Bilimleri" alanında ise ortak olarak verilen Din Kültürü ve Ahlak (1 saat) dersinin yanında herhangi bir Sosyal Bilimler dersi okutulmamaktadır. Daha önceden belirtildiği üzere bu alandaki öğrenciler isterlerse seçmeli dersler yoluyla Sosyal Bilimler derslerinden birini seçebilirler (http://ogm.meb.gov.tr/).

"Türkçe Matematik" alanında; 1 saat ortak ders olan Din Kültürü Ahlak dersinin yanında, sadece 2 saat Coğrafya dersi "alan dersi" olarak okutulmaktadır. Bu alanda Sosyal Bilimler derslerinin oranı \%10 dur (http://ogm.meb.gov.tr/). "Yabancı Dil” alanında ise, ortak olarak verilen, Din Kültürü Ahlak (1 saat) dersinin yanında alan dersi olarak herhangi bir Sosyal Bilimler dersi okutulmamaktadır (http://ogm.meb.gov.tr/). 
Grafik 2. Türkiye'de Lise Sosyal Bilimler Derslerinin Bölümlere ve Tüm Derslere Göre Oranı

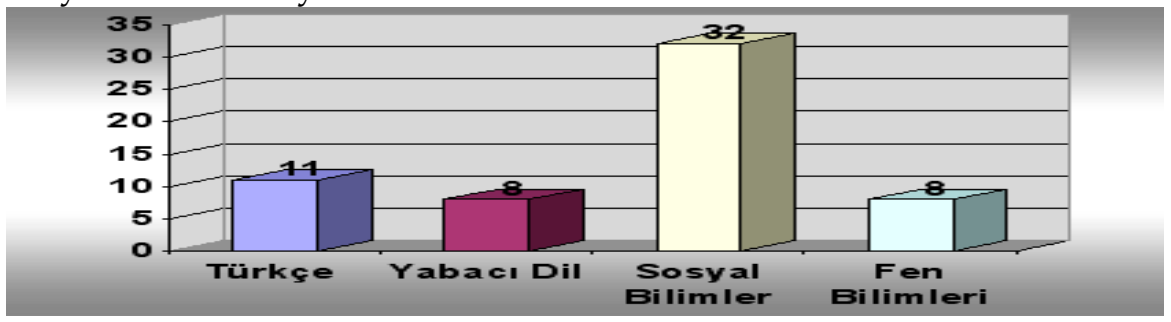

Kaynak: $\underline{\text { http://ogm.meb.gov.tr/ }}$

Grafik 2'nin de gösterdiği gibi lise Sosyal Bilimler dersleri tüm dersler içinde “Sosyal Bilimler" bölümünde \%32 “Türkçe-Matematik" bölümünde \%11 ve “Fen Bilimleri ve Yabancı Dil” Bölümünde \%8 ‘lik bir orana sahiptir.

\section{Sonuç ve Tartışma ve Öneriler}

Çalışma sonuçları, Türkiye'de genel liselerde okutulan Sosyal Bilimler derslerinin tek disiplin içinde yaklaşımının parçalı modeline göre disipliner bir anlayışla lise programlarına eklendiğini ortaya koymuştur

Bu çalışmada Almanya, Amerika Birleşik Devletleri, Fransa İngiltere ve Türkiye'nin Genel Lise Sosyal Bilimler programları incelenmiştir. Çalışmanın genel amacı olan beş ülkedeki genel lise Sosyal Bilimler programlarının karşılaştırmalı olarak incelenmesi sonucu birçok benzerlik ve farklılıklar ortaya konmuş ve bunlar tablolaştırılarak ilgili kısımlarda tartışılmıştır. Çalışmanın ana amacı olan “Türkiye lise Sosyal Bilimler programlarının Almanya, Amerika Birleşik Devletleri, Fransa ve İngiltere'nin Sosyal Bilimler lise programları ile karşılaştırılması "bölümünde, lise programlarında Sosyal Bilimler derslerine tüm dersler içinde en fazla ağırlık veren ülkenin \%30 ile Fransa olduğu tespit edilmiştir. İngiltere'de bu oran \%27, Almanya'da \%17 dir. Türkiye'de \%15, A.B.D 'nin Nebraska eyaletinde ise bu oran $\% 12$ dir.

Grafik 3. A.B.D. Almanya, Fransa ve Türkiye'deki Lise Sosyal Bilimler Derslerinin Dersler İçindeki Oranı

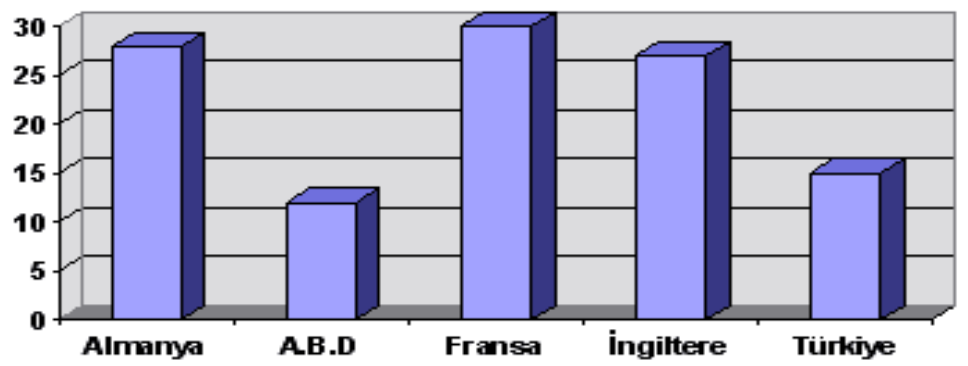

Grafik 3'de verilen oranların sınıflara göre dağılımı ise şöyledir. Almanya'da genel lise Sosyal Bilimler derslerinin tüm dersler içindeki oranının lise 11 . sınıfta \%17, 12 sınıfta $\% 18$ ve 13. sınıfta \%16 olduğu saptanmıştır. Fransa'da Sosyal Bilimler derslerinin tüm dersler içindeki oranına bakıldığında ise söz konusu derslerin Edebiyat bölümünde \%40, Ekonomi bölümünde $\% 35$, Fen Bilimleri bölümünde \%15 olduğu tespit edilmiştir. İngiltere'de 12.sınıfta bu oran \%25, 13.Sınıfta \%33 iken, Türkiye' de genel liselerde bölümlerin ortalaması alındığında 9 . sinıfta bu oran $\% 25,10$. sinıfta $\% 22,11$. sinıfta $\% 30,12$. sinifta ise $\% 21$ 'dir. 
Fernandez, Nassey ve Dombusch (2015) ve Singer (2003) de belirttiği üzere liselerde sosyal bilimler öğretiminin önemi açıkça ortaya konulmakta ve lise programları içinde sosyal bilimler derslerine verilen mevcut ağırlığın arttırılabileceği yönündedir

Ülkelerin toplumsal sorunlarını bilen, sorgulayan ve çözümü için öneriler geliştirebilen bireylerin yetiştirilmesinde Sosyal Bilimler öğretiminin önemi yadsınamaz bir gerçektir. Bu amaca ulaşmak üzere, bu araştırmada elde edilen sonuçlar ışığında aşağıdaki öneriler geliştirilmiştir.

1-Lise Sosyal Bilimler dersleri “Sosyal Bilimler" adı altında tek bir ders olarak ele alınmalıdır

Böylesi bir yaklaşım öğrencilerde genel bir Sosyal Bilim anlayışı oluşturulmasında yardımcı olacaktır. Bu dersin programının hazırlanmasında Sosyal Bilim dersini oluşturan alanlar arasındaki organik bağlantılar ortaya konarak, öğrencilerin hayatta karşılaştıkları toplumsal ve bireysel problemlerin çözümünde bütüncül bir anlayışı hayata geçirmeleri sağlanmaktadır

2-Sosyal Bilimler programının amaçları, öğrencilere kazandırılmak istenen beceri, tutum, değerler ve içerik belirlenen öğrenme alanları etrafında örüntülenmeli ve birbirleri arasındaki bağlantılar kurulmalıdır.

Öğrenme alanları bir dersin amaçlarına ve içeriğinin seçilmesine yön veren çerçevelerdir. Bu çerçevelerin içi ulusal ihtiyaçlar doğrultusunda doldurulmalıdır. Öğrenme alanlarının birçok disiplinle ilgili olabilme özelliğinden dolayı Sosyal Bilimler dersleri arasındaki bağlantıların kurulmasında oldukça işlevsel görülmektedir. Çalışmada incelenen ülkelerden Amerika Birleşik Devletleri'nde bu öğrenme alanlarının hayata geçirildiği ve diğer ülkelerin bu öğrenme alanlarını yazılı olarak belirtmeden benzer temaları işlediği tespit edilmiştir. Türkiye için de öğrenme alanlarının tespit edilmesi ve program amaç ve içeriğinin bu öğrenme alanları etrafında örüntülenmesi gerekliliği vardır.

3-Ortaöğretimdeki Sosyal Bilimler dersi programı ile İlköğretim kademesindeki Hayat Bilgisi ve Sosyal Bilgiler programları bir bütün olarak ele alınmalı, aralarındaki dikey bağlantılar kurulmalı ve bir Sosyal Bilgiler/Bilimler kültürü oluşturulmaya çalışılmalıdır.

Programların bütünleştirilmesi sürecinde benimsenen yatay ve dikey bağlantıların kurulması yaklaşımı Sosyal Bilgiler / Bilimler dersleri arasında da yaşama geçirilmelidir. Lise Sosyal Bilimler programı ile İlköğretim'deki Sosyal Bilgiler programı arasında amaç ve seçilen içerikler birbirini tamamlayacak şekilde düzenlenmelidir.

\section{Teşekkür ve Bilgilendirme}

Bu çalışma "Almanya, Amerika Birleşik Devletleri, Fransa, İngiltere ve Türkiye'de Genel Lise Sosyal Bilimler Programlarının Karşılaştırılması "adlı doktora tezinden elde edilmiştir. Bu anlamda tezin danışmanı olan Prof. Dr. Mehmet. A. Kısakürek’e teşekkür ederim. 


\section{Kaynakça}

Fernandez, C Massey. C ve Dombusch (2915) High School Students' Perceptions of Social Studies The Social Studies 67(2):51-57

Gardner W. ve Diğerleri (1997). Sosyal Bilimler Öğretimi. Ankara: YÖK/Dünya Bankası Milli Eğitimi Geliştirme Projesi Hizmet Öncesi Öğretmen Eğitimi.

Gulbenkian Komisyonu (1996). Sosyal Bilimleri Açın; Sosyal Bilimlerin Yeniden Yapılanması Üzerine Rapor Metis Yayınları.

Güven, İ. (2005). Sosyal Bilimlere Giriş Ders Notları, Ankara.

Hantrais, L. (1995), “Comparative Research Methods," Social Research Update. England: University of Surrey, Guildford GU2 7XH.

Kısakürek, M, A. (1981) Sosyal Bilimlerde Lisans Program Modelleri ve Programların Disipliner Analizi. Ankara: Ankara Üniversitesi Eğitim Fakültesi Yayınları no:100.

Kilimci S (2006) Almanya, İngiltere, Fransa ve Türkiye'de Sınıf Öğretmenliği Yetiştirme Programlarının Karşılaştırılması Yayımlanmamış Doktora Tezi Adana

Özoğlu, Ç., S. (1974). Liselerde Sosyal Bilimler Öğretimi. Ankara Üniversitesi Eğitim Fakültesi Yayınları no:38 Ankara

Philips, D. \& Ochs, K. (2004), Researching policy borrowing: some methodological challenges in comparative education, British Educational Research Journal, (30), (6).

Singer, A (2003) Social studies for secondary schools: Teaching to learn, learning to teach, 2nd edition Researcgate April 2003

Ültanır, G. (2000). Karşılaştırmalı Eğitim Bilimi Kuram ve Teknikler. Ankara: Eylül Yayincilik.

Varış, F. (1988). Eğitimde Program Geliştirme Teori ve Teknikler. (4. Baskı) Ankara: Ankara Üniversitesi Eğitim Bilimleri Fakültesi Yayınları no:157.

Yıldırım, A. \& Şimşek, H. (2005). Sosyal Bilimlerde Nitel Araştırma Yöntemleri. Ankara: Seçkin Kitabevi

\section{İnternet Kaynakları}

Almanya'daki genel ortaöğretim kurumlarının süreleri ve çeşitleri http://www.mszs.si/eurydice/pub/eurydice/Key_Data_2002/E_en_Secondary_2002_6994b.pdf

Bedford High School Curriculum (http://www.bedfordschool.org.uk/upload docs/AcademicCurriculumSept06.pdf)

Cozad High School Web Page in Nebraska

http://userweb.esu10.k12.ne.us/ cozad@esu10.org/chs/schedule.htm

Fransa da ortaöğretim eğitim sistemi http://www. iufm.fr/f qu-iufm.htm

İngiltere ortaöğretim Sistemi (http://www.inca.org.uk/england-system-mainstream.html)

Türkiye 9,10,11,12 sinıf Coğrafya Öğretim Programı MEB 2005 http://ogm.meb.gov.tr/ 